\title{
Pengelolaan Pajak Kendaraan Bermotor untuk Peningkatan Pendapatan Asli Daerah (PAD) di Kabupaten Lumajang
}

Yusuf Wibisono

Program Studi Akuntansi, STIE Widya Gama Lumajang

yusufwibisono1965@gmail.com

\begin{abstract}
Abstrak
Memasuki era otonomi daerah (Otoda) seperti sekarang, Pemerintah Daerah diberi kewenangan yang luas untuk menjalankan program-program pembangunan dan sekaligus untuk mewujudkan kesejahteraan masyarakat. Pembiayaan program-program pembangunan di daerah itu bersumber dari berbagai pendapatan daerah. Diantara salah satu sumber pendapatannya adalah pajak. Pajak yang menjadi primadona karena memiliki potensi besar, berpengaruh positif dan signifikan terhadap PAD adalah pajak kendaraan bermotor. Tujuan penelitian ini adalah untuk mengetahui perkembangan dan kontribusi Pajak Kendaraan Bermotor terhadap PAD di Kabupaten Lumajang selama dua tahun terakhir. Penelitian ini menggunakan pendekatan deskriptif kualitatif, metode penelitiannya menggunakan metode wawancara dan dokumentasi. Juga didukung dengan kajian pustaka yang relevan dengan pokok bahasan. Dari hasil penelitian dapat diketahui pengelolaan pajak kendaraan bermotor di Kabupaten Lumajang berjalan dengan baik dan berhasil melampui target setiap tahun. Hal itu sangat bermanfaat untuk menyumbang PAD Kabupaten Lumajang. Strategi dan kebijakankebijakan yang ditempuh oleh pemerintah guna meningkatkan pajak kendaraan bermotor, antara lain dengan melakukan pembenahan pengelolaan pajak kendaraan bermotor, baik SDM maupun birokrasinya. Meningkatkan pelayanan dengan pemanfaatan teknologi dan lain sebagainya.
\end{abstract}

\section{Kata kunci : Otonomi Daerah, Pajak Kendaraan Bermotor, PAD}

\section{Abstract}

The management of motor vehicle tax to increase PAD in Lumajang Regency Entering the era of regional autonomy (Otoda) as it is now, the Regional Government is given extensive authority to carry out development programs and at the same time to realize community welfare. Funding for development programs in the area comes from various regional revenues. Among the sources of income are taxes. The tax that is excellent because it has great potential, positive and significant impact on the PAD is motor vehicle tax. The purpose of this study was to determine the development and contribution of motor vehicle tax to PAD in Lumajang Regency over the past two years. This study uses a qualitative descriptive approach, the research method uses interview methods and documentation. Also supported by a literature review that is relevant to the subject matter. From the results of the study, it is known that the management of motor vehicle tax in Lumajang Regency runs well and successfully surpasses the target every year. This is very useful to contribute to the PAD of Lumajang Regency. The strategies and policies pursued by the government to increase motor vehicle tax, among others, by improving the management of motor vehicle tax, both Human Resources (HR) and bureaucracy. Improve services with the use of technology and so on.

Keywords: Regional Autonomy, Motor Vehicle Tax, PAD 


\section{PENDAHULUAN}

Lahirnya era Otonomi Daerah (Otoda) dipandang sangat strategis dalam konsep pembangunan di Indonesia. Sejak digulirkan produk Undang-Undang Nomor 22 Tahun 1999 dan disempurnakan dengan Undang-Undang Nomor 32 Tahun 2004 tentang Pemerintah Daerah, idealnya masing-masing Pemerintah Daerah dapat menggerakkan potensi yang dimiliki untuk membangun dan mensejahterakan rakyatnya. Paradigma Otoda bertumpu pada desentralisasi dan dekonsentrasi. Keduanya berjalan sebagai suatu yang bersifat kontinum. Namun secara umum paradigma Otoda menurut Undang-Undang Nomor 32 Tahun 2004 lebih mengedepankan aspek desentralisasi administrasi dibanding proses desentralisasi yang bersifat politik. Dengan artian, Otoda lebih cenderung pada political aspect. Sedangkan desentralisasi lebih cenderung pada administrative aspect.

Beberapa prinsip penting dalam pelaksanaan otonomi daerah meliputi prinsip otonomi seluasluasnya, prinsip otonomi nyata dan prinsip otonomi bertanggung jawab. 1) Prinsip Otonomi Seluas-Luasnya. Ini merupakan prinsip otonomi dimana daerah yang mendapat kewenangan dalam mengatur dalam hal pemerintahan dan mengatur kepentingan masyarakatnya. Namun, otonomi tersebut tidak memiliki kewenangan dalam hal politik luar negeri, agama, moneter, keamanan, peradilan, serta fiskan nasional. 2) Prinsip Otonomi Nyata. Ini adalah prinsip otonomi dimana daerah otonom memiliki kewenangan dalam menjalankan pemerintahan berdasarkan tugas, wewenang, dan kewajiban yang secara nyata telah ada. Tugas, wewenang, dan kewajiban tersebut berpotensi untuk berkembang sesuai dengan ciri khas daerah dan segala potensinya. 3) Prinsip Otonomi Bertanggungjawab. Ini adalah prinsip otonom dimana sistem penyelenggaraan harus sesuai dengan maksud dan tujuan dari pemberian otonomi. Pada dasarnya otonomi bertujuan agar daerah tersebut dapat berkembang dan masyarakatnya lebih sejahtera.

Penyelenggaraan otonomi daerah dilakukan berdasarkan tiga asas, yaitu a) Asas Desentralisasi. Ini merupakan pemberian wewenang untuk menjalankan pemerintahan kepada daerah otonom berdasarkan struktur NKRI dan dasar hukum yang berlaku. b) Asas Dekosentrasi. Ini merupakan pelimpahan wewenang dari pemerintah pusat kepada Gubernur yang bertugas sebagai wakil pemerintah dan atau perangkat pusat daerah.c) Asas Tugas Pembantuan. Ini merupakan pemberian tugas dari pemerintah pusat kepada pemerintah daerah untuk melaksanakan tugas tertentu dengan biaya, sarana dan prasarana, serta sumber daya manusia. Tugas tersebut harus dipertanggungjawabkan dan dilaporkan kepada yang berwenang. Untuk penyelenggaraan Otoda tersebut diperlukan kewenangan yang luas, nyata dan bertanggungjawab di Daerah serta adanya perimbangan antara keuangan pemerintah Pusat dan Daerah. Maka dengan Otoda itu daerah diberikan porsi yang besar untuk mengelola keuangan daerahnya. Ini berarti tanggung jawab menggali sumber-sumber keuangan daerah dan memanfaatkan penerimaan daerah lebih banyak berada didaerah.

Otonomi Daerah sejatinya mempunyai banyak dampak positif dalam menciptakan kemandirian masing-masing daerah. Akan tetapi dengan Otoda ini juga menjadi tantangan yang tidak ringan dalam proses pembangunan. Dalam menggali sumber-sumber keuangan daerah di era Otoda, sektor pajak menjadi salah satu sumber pembangunan daerah yang sangat signifikan. Pajak merupakan sumber pendapatan daerah yang dipandang mampu menjadi motor penggerak sekaligus sebagai pendorong peningkatan dan kesejahteraan masyarakat. Secara realita, pendapatan yang diperoleh dari pajak sangat dominan dan sekaligus sangat menentukan. Pemerintah kemudian membuat sejumlah Peraturan Daerah 
(Perda) yang mengatur pajak daerah, sesuai dengan UU Nomor 34 Tahun 2000 tentang perubahan atas UU Nomor 18 Tahun 1997 tentang Pajak Daerah dan Retribusi Daerah.

Meningkatnya peranan penerimaan pajak tersebut tidak lepas dari pembaharuan perpajakan yang telah dilaksanakan baik dalam tahun 1983 maupun dalam tahun 1994 yang lalu. Dalam tahun 1997 ini pelaksanaan ketentuan perpajakan yang baru dimaksud senantiasa diupayakan berdasar asas keadilan, pemerataan, dan kepastian hukum, selain juga diarahkan untuk memperkuat struktur dunia usaha dengan mendukung berkembangnya kelompok pengusaha kecil, menengah, dan koperasi. Seperti diketahui, jenis pajak berdasarkan wewenag yang memungut, terdiri dari pajak Negara (pajak pusat) dan pajak daerah. Yang relevan dengan pembahasan penelitian ini adalah pajak daerah. Yang dimaksud dengan pajak daerah adalah pajak yang kewenangan pemungutanya berada pada pemerintah Provinsi maupun Pemerintah Kabupaten/kota. Dalam Undang-Undang disebutkan bahwa Pajak Daerah adalah kontribusi wajib kepada daerah yang terutang oleh orang pribadi atau badan yang bersifat memaksa berdasarkan undang-undang dengan tidak mendapatkan imbalan secara langsung dan digunakan untuk keperluan daerah bagi sebesar-besarnya kemakmuran rakyat.

Berdasarkan ketentuan, pajak-pajak yang dipungut Daerah harus didasarkan pada Peraturan Daerah (Perda). Disamping itu , pajak daerah tidak boleh bertentangan dengan kebijakan Pemerintah pusat. Secara normatif demikian tetapi yang penting untuk dipehatikan dalam membuat Perda yang mengatur tentang pembebanan pajak kepada masyarakat, hendaklah dilakukan secara adil, tidak semata-mata untuk kepentingan mendapatkan jumlah pajak yang besar. Hasil evaluasi, pelaksanaan Otoda di beberapa Daerah telah diwarnai dengan kecenderungan Pemerintah Daerah untuk meningkatkan Pendapatan Asli Daerah (PAD)-nya dengan cara membuat Perda yang berisi pembebanan pajak-pajak daerah. Dampaknya, hal itu mengakibatkan timbulnya ekonomi biaya tinggi (high cost economy). Disinilah muncul dilema. Disatu sisi pajak itu sangat diperlukan dalam rangka menopang PAD. Pada sisi lain, banyaknya beban pajak-pajak itu dapat berujung pada timbulnya ekonomi biaya tinggi, sehingga bisa menyulut berbagai persoalan di masyarakat dengan resiko-resiko tertentu. Seharusnya segera disadari, upaya peningkatan pendapatan pajak dan restribusi daerah tidak semata-mata dengan memanfaatkan "range" kewenangannya untuk meningkatkan pendapatan pajak dan restribusi daerah, tetapi semua dilakukan secara adil dan proposional.

Pada konteks pengelolaan pajak kendaraan bermotor, Pemerintah telah memberikan penjelasan khusus. Sebagaimana tercantum pada penjelasan umum Peraturan Daerah Propinsi Jawa Timur Nomor 13 Tahun 2001 tentang pajak kendaraan bermotor, bahwa dalam rangka pembaharuan system perpajakan Daerah dan sejalan dengan perkembangan keadaan, maka pengaturan pajak kendaraan bermotor perlu diadakan penyesuaian dan penyempurnaan, sehingga dapat meningkatkan daya guna dan hasil guna serta terwujudnya peningkatan pelayanan kepada masyarakat dan pendapatan daerah. Gambaran secara umum, hasil dari pajak kendaraan bermotor ini di Jawa Timur sangat besar, sehingga ikut meningkatkan PAD, bahkan menjadi penyumbang terbesar PAD di Jawa Timur. Fokus masalah dalam penelitian ini berkenaan dengan pokok pengelolaan pajak kendaraan bermotor. Dari paparan diatas, dapat dirumuskan permasalahannya sebagai berikut 1) Faktor-faktor apakah yang berpengaruh dalam peningkatan Pendapatan pada sektor Pajak kendaraan bermotor ? 2) Strategi apa yang diambil dalam meningkatkan pendapatan Pajak kendaraan bermotor, sehingga realisasi dapat terus meningkat ? 3) Bagaimana kontribusi sektor pajak kendaraan bermotor terhadap pelaksanaan otonomi daearah, khususnya untuk peningkatan PAD ? 


\section{METODE PENELITIAN}

Penelitian ini merupakan penelitian deskriptif kualitatif, dimana peneliti bermaksud menganalisis data dengan cara mendeskripsikan atau mengambarkan data yang telah terkumpul sebagaimana adanya tanpa bermaksud membuat kesimpulan yang berlaku untuk umum atau generalisasi.

\section{HASIL DAN PEMBAHASAN}

Stakeholder dalam pengelolaan pajak kendaraan bermotor terdiri dari Unit Pelaksana Teknis (UPT) Badan Pendapatan Daerah Provinsi Jawa Timur Lumajang, Polantas dan PT. Jasa Raharja. UPT Badan Pendapatan Daerah melakukan penarikan PKB dan BBNKB. Polantas melakukan pelayanan registrasi dan identifikasi kendaraan bermotor. Sedang PT. Jasa Raharja melaksanakan pungutan sumbangan wajib dana kecelakaan lalu lintas jalan Dalam pembahasan ini dibatasi khusus pengelolaan pajak kendaraan bermotor (PKB) dan Bea Balik Nama Kendaraan Bermotor (BBNKB) oleh (UPT) Badan Pendapatan Daerah Provinsi Jawa Timur Lumajang.

Gambaran secara umum, hasil dari pajak kendaraan bermotor ini di Jawa Timur sangat besar, sehingga ikut meningkatkan PAD, bahkan menjadi penyumbang terbesar PAD di Jawa Timur. Seperti di tulis di Republika.co.id. Menurut Sekretaris Daerah Provinsi Jawa Timur, Akhmad Sukardi, realisasi penerimaan sektor Pajak Kendaraan Bermotor (PKB) dan sektor Bea Balik Nama Kendaraan Bermotor (BBNKB) di Jawa Timur pada 2016 mencapai Rp 9,01 triliun. Dua sektor tersebut menjadi penyumbang terbesar bagi PAD Jawa Timur pada 2016 yang terealisasi sebesar Rp 12,84 triliun.

Data rincinya sebagai berikut : realisasi penerimaan sektor PKB Jatim sebesar Rp 5,30 triliun atau mencapai 106,2 persen, dari target yang dicanangkan sebesar Rp 5 triliun. Sementara realisasi sektor BBNKB Jatim sebesar Rp 3,71 triliun atau mencapai 112,44 persen dari target awal Rp 3,3 triliun. Di tingkat lokal Lumajang, hasil dari pajak kendaraan bermotor ini juga menjadi primadona. Dalam sepuluh tahun terakhir rata-rata menunjukkan angka kenaikan. Hal itu berarti pajak kendaraan bermotor sekaligus juga menjadi penyumbang primadona PAD Pemerintah Kabupaten Lumajang.

Data yang dapat diperoleh di (UPT) Badan Pendapatan Daerah Provinsi Jawa Timur Lumajang Tahun 2017 dan 2018 menyebutkan, di Kabupaten Lumajang untuk Tahun 2017 memperoleh Pajak Kendaraan Bermotor (PKB) sebesar Rp. 85.820.494.667,-- Dan memperoleh pajak BBNKB sebesar Rp. 41.857.139.500,-. Kemudian tahun 2018 memperoleh Pajak Kendaraan Bermotor (PKB) sebesar Rp. 93.995.902.550,- Dan memperoleh pajak BBNKB sebesar Rp. 47.502.667.400,- Total hasil dari pajak ranmor dari PKB dan BBNKB selama tahun 2017 di Lumajang mencapai Rp. 127.677.634.167,,-- Dan pajak ranmor dari PKB dan BBNKB tahun 2018 sebesar Rp. 141.498.569.950,- Angka tersebut masih bisa dioptimalkan lagi dengan kesadaran wajib pajak untuk melaksanakan kewajibannya. Sebab masih ada wajib pajak yang mangkir tidak melaksanakan kewajibannya untuk membayar PKB dan BBNKB.

Dari data tersebut dapat diketahui, perolehan pajak kendaraan bermotor (PKB) dan Bea Balik Nama Kendaraan Bermotor (BBNKB) selama dua tahun terakhir dapat melampui target. Ada dua strategi penting yang dilakukan untuk mengelola pajak kendaraan bermotor di Lumajang. Yaitu strategi internal antara lain menyangkut regulasi tentang pengelolaan pajak kendaraan 
yang relevan dengan perkembangan, dengan tidak terlalu membebani masyarakat, bahkan sebaliknya ada tawaran-tawaran yang meringankan beban masyarakat. Lalu menyangkut penataan birokrasi, penyederhanan pelayanan untuk mempermudah masyarakat serta hal-hal yang menyangkut kode etik pelayanan. Dan strategi eksternal menyangkut kerjasama dengan lembaga lain dan hubungannya dengan masyarakat. Dalam hal ini menyangkut antara lain tentang pentingnya sosialisasi tentang pajak, pemberian motivasi yang didalamnya menyangkut penghargaan (reward) kepada pembayar pajak dan pemberian sanksi (punishment) bagi yang tidak membayar alias nunggak pajak sampai batas waktu tertentu, dan lain sebagainya.

Menurut Sigit sebagai Pengelola Data Pelayanan Perpajakan pada Kantor Samsat Lumajang, ada beberapa faktor penting yang mampu mendongkrak perolehan pajak kendaraan bermotor di Kabupaten Lumajang sehingga melampui target. Diantaranya, dipengaruhi oleh daya beli masyarakat yang meningkat. Jumlah kendaaraan baru setiap tahun sekitar 14.000 sampai 15.000 kendaraan. Misalnya, tahun 2018 jumlah kendaraan baru jenis sepeda motor sebanyak 11.800. sedangkan kendaraan roda empat (mobil) sebanyak 2.433. Kemudian, tumbuhnya kesadaran masyarakat untuk menunaikan kewajibannya dalam membayar pajak. Hal itu didukung oleh makin tersesosialisaikannya ketentuan Undang-Undang (UU), Peraturan Daerah (Perda) dan peraturan-peraturan lainnya tentang pajak kendaraan bermotor.

Layanan kepada masyarakat makin dioptimalkan, sehingga masyarakat semakin mudah untuk menunaikan kewajibannya membayar pajak kendaraan bermotor. Dimana pelayanan pembayaran pajak kendaraan bermotor tidak lagi terpusat di Samsat Lumajang, tetapi bisa dilayani di Kecamatan-Kecamatan dengan system layanan keliling yang sudah terjadwaL. Menurut Sigit Bodro, rata-rata perolehan pajak setiap tahun bisa melampui target. Tetapi perolehan pajak kendaraan bermotor pernah tidak sampai mencapai target, yaitu pada tahun 2015. Salah satu sebabnya adalah target yang dibuat terlalu tinggi. Juga disampaikan, pengelolaan pajak kendaraan bermotor masih perlu dioptimalkan, karena masih ada wajib pajak yang tidak menunaikan kewajibannya, dan itu berarti menjadi tunggakan yang perlu ditangani.

Sigit menyampaikan beberapa kiat-kiat yang telah dilakukan untuk mengoptimalkan pengelolaan pajak kendaraan bermotor di Lumajang, antara lain dengan strategi jemput bola. Samsat Lumajang menerjunkan armada kendaraan mobil dan sepeda motor untuk melayani masyarakat dalam pembayaran kendaraan bermotor di Kecamatan-Kecamatan se Kabupaten Lumajang. Samsat Lumajang juga membuka layanan untuk pembayaran pajak kendaraan bermotor pada malam hari. Seperti layanan malam hari di halaman Bank Jatim Barat Alunalun Lumajang dan layanan malam hari di perempatan barat Pasar baru Lumajang. Layanan malam hari ini untuk memberi kesempatan kepada masyarakat yang siang hari tidak berkesempatan, dapat melakukannya pada malam hari.

Samsat Lumajang bekerjasama dengan Bank Jatim untuk melayani pembayaran pajak kendaraan bermotor satu atap di Bank Jatim, baik yang ada di Kabupaten Lumajang maupun di beberapa Kecamatan di Lumajang. Demikian beberapa kiat dan strategi yang dilakukan oleh Samsat Lumajang dalam rangka optimalisasi pengelolaan pajak kendaraan bermotor di Kabupaten Lumajang.Tak kalah pentingnya, Samsat Lumajang juga menciptakan system dan prosedur yang sederhana. Menciptakan lingkungan Samsat yang menyenangkan. Menyediakan tempat pengaduan dan informasi. Menerapkan system pelayanan KB Samsat 
berbasis teknologi informasi, media dan telekomunikasi, salah satunya membuka layanan SMS 7070.

Terkait dengan kedaraan masyarakat membayar pajak kendaraan bermotor ini ada salah satu faktor yang ikut menentukan, yakni makin dioptimalkannya pemberlakukan ketentuan saksi bagi kendaraan yang tidak diperpanjang selama dua tahun lebih. Menurut UU Nomor 22 Tahun 2009 tentang Lalu Lintas Dan Angkutan Jalan, antara lain bagi pemilik kendaraan yang tidak melakukan perpanjangan Surat Tanda Nomor Kendaraan Bermotor (STNK) selama dua tahun, sejak masa berlaku lima tahunan STNK habis, kendaraannya akan menjadi kendaraan bodong. Karena bodong, maka kendaraan tersebut tidak bisa diregistrasi dan identifikasi (regident) kendaraan bermotor.

Menyangkut strategi dalam mengoptimalkan perolehan pajak, Samsat Lumajang melakukan motivasi kepada masyarakat dalam bentuk pemberian reward dan penerapan punishment. Mengutip pendapat tentang penerapan reward dan punishment ini, keduanya sudah lazim diterapkan di berbagai aspek kehidupan, seperti di dunia pendidikan, dunia olah raga, termasuk didunia kerja dan kegiatan bisnis. Relevan dengan hal ini, menurut Deddy Mulyadi (2015 : 34-35) ada empat hal yang saling berkaitan dan dapat dijalankan secara terpadu, yaitu positive reinforcement dengan pemberian reward atau penghargaan. Negative reinforcement yaitu memberikan konsekusnsi yang tidak menyenangkan. Lalu punishment berupa sanksi untuk menghentikan atau menghilangkan perilaku yang tidak diinginkan. Dan extinction berupa pemotongan pendapatan atau gaji dan lain-lainnya.

Samsat telah memberikan reward antara lain berupa pemutihan kendaraan bermotor. Salah satu regulasi yang memberi keringanan kepada masyarakat adalah Peraturan Gubernur Jawa Timur Nomor 67 Tahun 2017. Peraturan Gubernur ini memberi keringanan kepada masayarakat untuk melakukan pemutihan kendaraan bermotor. Sebagaimana dimuat di https://news.detik.com/berita-jawa-timur/d-3692607/hore-pemprov-jatim-beri-pemutihan-

denda-pajak-dan-bebas-bbn, Pemerintah Provinsi Jawa Timur memberikan pemutihan. Pemutihan berlaku untuk denda pajak serta memberikan kebebasan pada bea balik nama (BBN) kendaraan bermotor. Menurut Kepala Badan Pendapatan Daerah Provinsi Jawa Timur Bobby Soemiarsono, Gubernur Jawa Timur memberikan keringanan, pembebasan dan insentif pajak daerah untuk rakyat Jawa Timur tahun 2017.

Peraturan tentang pemutihan juga berlaku untuk tahun 2018. Gubernur Jawa Timur Soekarwo telah membuat Pergub nomor 88/2018 tentang Pembebasan Pajak Daerah untuk Rakyat Jatim dengan pemutihan pajak. Layanan pemutihan pajak kendaraan dan gratis biaya balik nama (BBN) mulai dibuka tanggal 24 September sampai tanggal 15 Desember 2018. Seperti ditulis di http://suryamalang.tribunnews.com/2018/09/20/program-pemutihan-pajak-kendaraanbermotor-di-jatim-mulai-24-september-2018-perhatikan-syaratnya, Kombes Pol Heri Wahono, Dirlantas Polda Jatim mengatakan pembebasan pajak daerah itu meliputi pembebasan pokok bea balik nama kendaraan bermotor atas penyerahan kedua dan pembebasan sanksi administratif pajak kendaraan dan bea balik nama kendaraan bermotor.

Adanya peraturan tentang pemutihan pajak ini maka semua wajib pajak kendaraan yang nunggak akan diputihkan dendanya dan hanya membayar pajak pokok saja. Demikian juga bagi pembeli kendaraan tangan kedua dan seterusnya juga dibebaskan biaya BBN, baik kendaraan roda dua maupun roda empat dan seterusnya. Kebijakan Pemutihan tersebut merupakan wujud nyata pemerintah daerah untuk meringankan beban rakyat Jatim sekaligus 
meningkatkan kesadaran patuh membayar pajak kendaraan bermotor, bea balik nama kendaraan bermotor, penerimaan Negara bukan pajak (PNBP), sumbangan wajib dana kecelakaan di jalan serta pengesahan surat tanda nomor kendaraan setiap tahun. Penerapan strategi ini mendapat respon positif dan masyarakat menjadi antusias membayar PKB dan BBNKB. Sedangkan punishment berupa sanksi bagi yang tidak melakukan perpanjangan Surat Tanda Nomor Kendaraan Bermotor (STNK) selama dua tahun, sejak masa berlaku lima tahunan STNK habis, sebagaimana disebutkan diatas, sesuai dengan ketentuan UndangUndang Nomor 22 Tahun 2009 tentang Lalu Lintas Dan Angkutan Jalan. Dalam pasal 74 (2) disebutkan bahwa bagi pemilik kendaraan yang tidak melakukan perpanjangan Surat Tanda Nomor Kendaraan Bermotor (STNK) selama dua tahun, sejak masa berlaku lima tahunan STNK habis, kendaraannya akan menjadi kendaraan bodong. Karena bodong, maka kendaraan tersebut tidak bisa diregistrasi dan identifikasi (regident) kendaraan bermotor.

Aturan punishment seperti itu ternyata memiliki pengaruh yang positif untuk memotivasi masyarakat agar mereka taat memperpanjang kendaraannya. Masyarakat akan menjadi jera atau takut kalo tidak mau memperpanjang kendaraannya, maka kendaraannya menjadi bodong. Strategi ini bisa dilakukan untuk mengurangi jumlah tunggakan pajak yang belum dibayar oleh para wajib pajak. Peraturan ini sudah berlaku sejak tahun 2009, dan sekarang sedang diintensifkan dan dioptimalkan untuk bisa dilaksanakan secara efektif. Hasil pengelolaan pajak kendaraan bermotor tersebut disetorkan ke Badan Pendapatan Daerah Pemerintah Provinsi Jawa Timur. Selanjutnya dilakukan bagi hasil pengelolaan pajak antara Provinsi dan Kabupaten/Kota sesuai dengan ketentuan. Perlu diketahui, bagi hasil dari pengelolaan pajak kendaraan bermotor, masing-masing Daerah akan mendapat bagi hasil pajak sebesar $30 \%$ dari jumlah komulatif penerimaan pajaknya yang menjadi Pendapatan Asli Daerah (PAD) Kabupaten/Kota. Sebagaimana diamanatkan oleh Undang-Undang Nomor 32 Tahun 2004 tentang Perimbangan Keuangan antara Pemerintah Pusat dan Pemerintahan Daerah, salah satu sumber pendanaan Pemerintahan Daerah adalah Pendapatan Asli Daerah (PAD), yang bersumber dari pemungutan Pajak dan Retribusi Daerah, hasil pengelolaan kekayaan daerah yang dipisahkan, dan lain-lain PAD yang sah.

Bagi hasil dari pengelolaan pajak kendaraan bermotor di Jawa Timur diatur lebih lanjut dalam Peraturan Daerah Provinsi Jawa Timur Nomor 9 Tahun 2010, antara lain disebutkan bahwa Hasil Penerimaan Pajak Kendaraan Bermotor (PKB) dan Bea Balik Nama Kendaraan Bermotor (BBNKB) diserahkan kepada Pemerintah Kabupaten dan Pemerintah Kota sebesar $30 \%$. Sedangkan diserahkan kepada Pemerintah Provinsi sebesar 70\%. Dengan demikian, nampak jelas dalam proses pengelolaan pajak kendaraan bermotor di Provinsi Jawa Timur dapat memberikan kontribusi terhadap PAD Pemerintah Kabupaten/Kota. Pada gilirannya dapat menunjang pelaksanaan pembangunan di Daerah setempat. Di Kabupaten Lumajang pengelolaan pajak kendaraan bermotor menjadi salah satu sumber primadona pada PAD Pemkab. Lumajang.

Sektor pajak kendaraan bermotor (PKB) dan Bea Balik Nama Kendaraan Bermotor (BBNKB) menjadi sumber primadona PAD. Seperti data yang dipaparkan diatas, pengelolaan PKB dan BBNKB selama dua tahun terakhir menunjukkan peningkatan dan dapat melampui target dibuat. Hal itu tentu akan mampu memberikan kontribusi bagi PAD Kabupaten Lumajang. Untuk tahun 2017 pengelolaan PKB dan BBNKB berhasil menghimpun pajak Rp. 127.677.634.167,- Sedangkan untuk tahun 2018 pengelolaan PKB dan BBNKB mengalami kenaikan karena berhasil menghimpun pajak sebesar Rp. 141.498.569.950,-. Perolehan pajak kendaraan bermotor di Kabupaten Lumajang tahun 2017 dan 2018 itu mampu melampui 
target pertahunnya, yakni Rp. 116.226.150.000,- untuk tahun 2017 dan Rp. 119.555.000.000,- untuk tahun 2018.

Kalkulasi bagi hasil pajak kendaraan bermotor tersebut, dapat diketahui bahwa pengelolaan PKB dan BBNKB selama tahun 2017 di Kabupaten Lumajang telah dapat menyumbang PAD Kabupaten Lumajang sebesar Rp. 38.303.290.250,- Kemudian lebih meningkat lagi pada tahun 2018 menjadi sebesar Rp. 42.449.570.985,- Dari sumbangsih pajak dari PKB dan BBNKB sebesar itu, tepatlah jika dikatakan bahwa pajak yang diperoleh dari PKB dan BBNKB menjadi sumber pajak primadona. Besarnya sumbangan pajak dari PKB dan BBNKB Kabupaten Lumajang dapat dibadingkan dengan jumlah komulatif sumbangan pajak PKB dan BBNKB Kabupaten/Kota se Jawa Timur kepada Pemerintah Provinsi Jawa Timur. Dimana dua sektor pajak tersebut telah menjadi penyumbang terbesar bagi Pendapatan Asli Daerah (PAD) Jawa Timur pada 2016 yang terealisasi sebesar Rp 12,84 triliun.

Republika.co.id, menuliskan bahwa Akhmad Sukardi yakni Sekretaris Daerah Provinsi Jawa Timur menyampaikan, realisasi penerimaan sektor Pajak Kendaraan Bermotor (PKB) dan sektor Bea Balik Nama Kendaraan Bermotor (BBNKB) di Jawa Timur pada 2016 mencapai Rp 9,01 triliun. Dua sektor tersebut menjadi penyumbang terbesar bagi Pendapatan Asli Daerah (PAD) Jatim pada 2016 yang terealisasi sebesar $\mathrm{Rp} 12,84$ triliun. Data rincinya sebagai berikut : realisasi penerimaan sektor PKB Jatim sebesar Rp 5,30 triliun atau mencapai 106,2 persen, dari target yang dicanangkan sebesar Rp 5 triliun. Sementara realisasi sektor BBNKB Jatim sebesar Rp 3,71 triliun atau mencapai 112,44 persen dari target awal Rp 3,3 triliun. Akhirnya, dari keseluruhan dapat disimpulkan bahwa hasil analisis penerimaan pajak kendaran bermotor di Kabupaten Lumajang sudah sangat baik. Penerimaan pajak kendaraan bermotor berhasil melampui target setiap tahun. Hal itu antara lain didukung dengan kinerja yang baik dari pihak-pihak terkait, dan yang terpenting adalah ketaatan para wajib pajak dalam menunaikan kewajibannya, sehingga dari tahun ke tahun selalu memenuhi target yang telah ditetapkan.

\section{KESIMPULAN}

Penelitian ini dapat diambil beberapa kesimpulan sebagai berikut : 1) Pengelolaan pajak kendaraan bermotor di Kabupaten Lumajang berkembang dengan baik dan mampu melampui target setiap tahunnya. Hal itu disebabkan oleh banyak faktor yang penting dan berpengaruh, diantaranya, makin meningkatnya daya beli masyarakat, tumbuhnya kesadaran masyarakat untuk taat membayar pajak dan respon baik masyarakat atas pelayanan prima yang dilakukan oleh Samsat Kabupaten Lumajang. 2) Secara umum ada dua strategi yang dilakukan oleh Samsat Lumajang dalam mengoptimalkan pengelolaan pajak kendaraan bermotor di Kabupaten Lumajang, yaitu strategi internal dan strategi eksternal. Untuk Strategi internal antara lain menyangkut regulasi tentang pengelolaan pajak kendaraan yang relevan dengan perkembangan, penataan birokrasi, penyederhanan pelayanan untuk mempermudah masyarakat serta hal-hal yang menyangkut kode etik pelayanan. Sedangkan strategi eksternal menyangkut kerjasama dengan lembaga lain dan hubungannya dengan masyarakat. Antara lain tentang pentingnya sosialisasi tentang pajak, pemberian motivasi berupa penghargaan (reward) kepada mereka yang taat membayar pajak dan pemberian sanksi (punishment) bagi yang tidak membayar alias nunggak pajak sampai batas waktu tertentu. 3) Kontribusi pajak kendaraan bermotor pada PAD Kabupaten Lumajang sangat besar. Pengelolaan PKB dan BBNKB selama tahun 2017 di Kabupaten Lumajang telah dapat menyumbang PAD Kabupaten Lumajang sebesar Rp. 38.303.290.250,- Kemudian lebih meningkat lagi pada 
tahun 2018 menjadi sebesar Rp. 42.449.570.985,- Dari sumbangsih pajak dari PKB dan BBNKB sebesar itu, tepatlah jika dikatakan bahwa pajak yang diperoleh dari PKB dan BBNKB menjadi sumber pajak primadona. Dan besarnya sumbangan pajak dari PKB dan BBNKB Kabupaten Lumajang seperti itu dapat dibadingkan dengan jumlah komulatif sumbangan pajak PKB dan BBNKB Kabupaten/Kota se Jawa Timur kepeda Pemerintah Provinsi Jawa Timur dengan hasil yang sangat besar. Dimana dua sektor pajak tersebut telah menjadi penyumbang terbesar bagi Pendapatan Asli Daerah (PAD) Jawa Timur, mencapai angka triliunan rupiah.

Relevan dengan hasil penelitian dan pembahasan, maka perlu disampaikan beberapa saran kepada para wajib pajak untuk taat menuinaikan kewajibannya dalam menunaikan pajak, khususnya pajak kendaraan bermotor dalam rangka menopang pelaksanaan program-program pembangunan daerah baik di Provinsi maupun di Kabupaten/Kota. Kepada Badan Pendapatan Daerah Provinsi Jawa Timur dan Samsat Lumajang untuk dapat mengelola pajak kendaraan bermotor dengan penuh amanah, professional dan akuntabel, serta membagi hasil pungutan pajak secara adil dan proporsional, sehingga hasil pungutan pajak PKB dan BBNKB bermanfaat dalam menyumbang Pendapatan Asli Daerah (PAD) baik di Provinsi maupun di Kabupaten/Kota. Kepada Pemerintah Kabupaten Lumajang yang memperoleh bagi hasil dari pengelolaan pajak untuk dimasukkan dalam Pendapatan Asli Daerah (PAD) bersama pendapatan asli daerah lainnya, untuk membuat program-program pembangunan yang membawa manfaat dan kesejuahteraan untuk semua masyarakat, mewujudkan Kabupaten Lumajang yang makmur, sejahtera dan bermartabat.

\section{DAFTAR PUSTAKA}

Pohan, Chairil Anwar. (2017). Perpajakan Indonesia Teori dan Kasus. Jakarta: Mitra Wacana Media.

Hidayat, Nurdin dan Dedi Purwana. (2007). Perpajakan Teori Dan Praktik. Jakarta: Rajawali Pers.

Mardiasmo. (2016). Perpajakan. Yogyakarta: ANDI.

Mulyadi, Dedy. (2015). Perilaku Organisasi Dan Kepemimpinan Pelayanan, Konsep Dan Aplikasi. Bandung: Alfabeta.

Sambodo, Agus. (2005). Pajak Dalam Entitas Bisnis. Jakarta: Salemba Empat.

Sidarto Danusubroto. (2006). DPR Bukan Taman Kanak-Kanak, Produktifitas Dewan Versus Kesenjangan Birokrasi. Jakarta: Verbum Publishing.

Soemitro R. (2002). Pengantar Singkat Hukum Pajak. Bandung: PT. Eresco. Undang-Undang Nomor 34 tahun 2000 tentang Pajak Daerah dan Retribusi daerah Undang-Undang Nomor 32 Tahun 2004 tentang Pemerintahan Daerah Undang-Undang Nomor 33 Tahun 2004 tentang Perimbangan Keuangan Antara Pemerintah Pusat Dan Pemerintah Daerah Undang-Undang Nomor 22 Tahun 2009 tentang Lalu Lintas Dan Angkutan Jalan Tap MPR No. IV/ MPR/2000 tentang rekomendasi kebijakan dalam penyelenggaraan otonomi daerah

Peraturan Daerah Provinsi Jawa Timur Nomor 13 Tahun 2001 tentang Pajak Kendaraan Bermotor

Peraturan Daerah Provinsi Jawa Timur Nomor 14 Tahun 2001 tentang Bea Balik Nama Kendaraan Bermotor

https://republika.co.id/berita/ekonomi/keuangan/17/02/26/olzk9x319-realisasi-pkb-danbbnkb-jatim-capai-rp-9011-triliun . 
http://harianbhirawa.com/2018/11/realisasi-pajak-kendaraan-bermotor-capai-10303-persen. https://news.detik.com/berita-jawa-timur/d-3692607/hore-pemprov-jatim-beri-pemutihandenda-pajak-dan-bebas-bbn.

http://suryamalang.tribunnews.com/2018/09/20/program-pemutihan-pajak-kendaraanbermotor-di-jatim-mulai-24-september-2018.

http://www.memotimurlumajang.id/2017/10/penerimaan-pbb-lumajang-capai-84-persen.html 